\title{
Core competencies: Mapping the Vision-Aligned Academic Framework into the Vision Project
}

\author{
Noah P. Barsky \\ Dawn W. Massey \\ Fairfield University, dmassey@fairfield.edu \\ Jay Thibodeau
}

Follow this and additional works at: https://digitalcommons.fairfield.edu/business-facultypubs Copyright 2003 Emerald

\section{Peer Reviewed}

\section{Repository Citation}

Barsky, Noah P.; Massey, Dawn W.; and Thibodeau, Jay, "Core competencies: Mapping the Vision-Aligned Academic Framework into the Vision Project" (2003). Business Faculty Publications. 87.

https://digitalcommons.fairfield.edu/business-facultypubs/87

\section{Published Citation}

Noah P. Barsky, Dawn Massey and Jay Thibodeau. 2003. "Core competencies: Mapping the Vision-Aligned Academic Framework into the Vision Project." Advances in Accounting Education: Teaching and Curriculum Innovations, Volume 5, pp. 129-142.

This item has been accepted for inclusion in DigitalCommons@Fairfield by an authorized administrator of DigitalCommons@Fairfield. It is brought to you by DigitalCommons@Fairfield with permission from the rightsholder(s) and is protected by copyright and/or related rights. You are free to use this item in any way that is permitted by the copyright and related rights legislation that applies to your use. For other uses, you need to obtain permission from the rights-holder(s) directly, unless additional rights are indicated by a Creative Commons license in the record and/or on the work itself. For more information, please contact digitalcommons@fairfield.edu. 


\title{
CORE COMPETENCIES: MAPPING THE VISION-ALIGNED ACADEMIC FRAMEWORK INTO THE VISION PROJECT
}

\author{
By
}

\author{
Noah P. Barsky \\ Assistant Professor of Accountancy \\ Villanova University \\ College of Commerce \& Finance \\ Department of Accountancy \\ 800 Lancaster Avenue \\ Villanova, PA 19085-1678 \\ Phone: 610/519-6272 \\ Fax: 610/519-5204 \\ Email: noah.barsky@villanova.edu
}

\author{
Dawn W. Massey* \\ Assistant Professor of Accounting \\ Fairfield University \\ Charles F. Dolan School of Business \\ 1073 North Benson Road \\ Fairfield, CT 06430-7524 \\ Phone: 203/254-4000 x2844 \\ Fax: 203/254-4105 \\ Email:dmassey@mail.fairfield.edu
}

Jay C. Thibodeau

Associate Professor of Accounting

Bentley College

Department of Accountancy

175 Forest Street

Waltham, MA 02154-4705

Phone: 781/891-2564

Fax: 781/891-2896

Email: jthibodeau@bentley.edu

*Corresponding Author 


\begin{abstract}
The AICPA issued its Vision-Aligned Academic Framework (2000) to assist faculty in modifying curricula to support students' development of the Core Competencies that the AICPA previously articulated in its Vision Project (1999). The Framework provides extensive detail about twenty different Competency Dimensions in an effort to aid educators in defining learning objectives that better incorporate the Vision Project's five Core Competencies. However, at present, there is a gap between the Framework and the Vision Project in that there is no explicit mapping of the Framework's Competency Dimensions to each of the Vision Project's Core Competencies. Given the importance of the Framework in developing learning objectives that reflect the Vision Project's Core Competencies, this paper extends the academic literature by mapping each Competency Dimension in the Framework to a specific Core Competency in the Vision Project. In so doing, this manuscript supports the AICPA's conceptual modeling process by providing an explicit mapping that will help accounting educators in their efforts to expeditiously integrate into their curriculum the Vision Project's Core Competencies.
\end{abstract}




\section{CORE COMPETENCIES: MAPPING THE VISION-ALIGNED ACADEMIC FRAMEWORK INTO THE VISION PROJECT}

Over the past decade, many prominent professional and academic bodies have called for change in accounting education curriculum to better meet the needs of the profession. Most recently, Albrecht and Sack (2000, 43) observed that accounting education "focus(es) too much on content at the expense of skill development—skills our students need to be successful professionals." To effectively change curriculum, Bonner $(1999,13)$ suggests that educators must consider market forces and define learning objectives more broadly than the topical content coverage set forth in popular textbooks.

For instance, in 1999, the AICPA, through its Vision Project, articulated five broad "Core Competencies" necessary for accounting professionals in the $21^{\text {st }}$ Century. Walker and Ainsworth $(2001,43)$ observed that the AICPA's competencies are not structured around the traditional content areas in accounting curriculum. To assist faculty in modifying "curricula to support the development of [these] competencies," the AICPA followed with its Vision-Aligned Academic Framework (2000, http://www.aicpa.org/edu/overview.htm). The Framework provides considerable detail about twenty different "Competency Dimensions" (e.g., activities), which are consistent with, but not explicitly mapped to, each of the Vision Project's five Core Competencies (AICPA 1999). 
As Bonner $(1999,12)$ suggests, well-defined learning objectives should drive course content and activities. The AICPA's Vision provides educators with a prominent, market-based structure to consider and select course objectives. This paper extends the academic literature by supporting the AICPA's conceptual models by mapping each Competency Dimension of the Framework to a specific Core Competency. This mapping helps educators to select course content that enables expeditious implementation of course goals that reflect market expectations.

We organize the remainder of this paper as follows. In the next section, we summarize the five Core Competencies outlined in the Vision Project (AICPA 1999) and the twenty Competency Dimensions outlined in the Vision-Aligned Academic Framework (AICPA 2000). Then, we integrate the AICPA's two pronouncements by mapping each Competency Dimension to a specific Core Competency. The final section presents our conclusions and limitations.

\section{COMPETENCIES FOR FUTURE ACCOUNTING PROFESSIONALS}

For more than a decade, various sectors of the accounting profession have devoted their attention to identifying the characteristics that successful future accountants will need (e.g., Bedford Committee 1986; Big 8, 1989; Institute of Management Accountants 1994, 1999). In 1999, in representation of the accounting profession as a whole, the AICPA issued its Vision Project report, 
Focus on the Horizon, the CPA Profession in 2011 (AICPA 1999). In 2000, the AICPA issued the Vision-Aligned Academic Framework (AICPA 2000) as a follow-up to the 1999 Vision Project.

\section{AICPA Vision Project}

The AICPA's (1999) Vision Project was an unprecedented, grassroots initiative whose purpose was to provide an assessment of what the future is likely to hold for the CPA profession. In its Vision Project report, the AICPA (1999, 17 18) suggests that there are five Core Competencies that accountants will need to succeed in business. They are: (1) communications and leadership skills; (2) focus on the customer, client and market; (3) technological adeptness; (4) interpretation of converging information; and (5) strategic and critical thinking skills. Drawing from the Vision Project report (AICPA 1999), we summarize each of the Core Competencies in Table 1 and describe each below.

\section{INSERT TABLE 1 HERE}

\section{Communications and Leadership Skills}

Communications and leadership skills relate to an individual's ability to convey information to others in a way that is understandable, motivational and convincing. This skill depends on an understanding of a company's or a client's business strategy. This background knowledge provides an important foundation 
that helps accountants become active listeners, able to ask the right questions and deliver credible insight into different business issues.

Focus on the Customer, Client and Market

Underlying accountants' communication and leadership skills is their ability to focus on the needs of customers, clients and markets. This Core Competency requires accountants to ask targeted questions that elicit information to assess current needs and anticipate future needs. To do so, accountants must keep abreast of market and industry-specific trends as they affect clients.

\section{Technological Adeptness}

Accountants who are technologically adept will "utilize and leverage technology in ways that add value to clients, customers, and employees" (AICPA 1999, 18). This competency requires accountants not only to use extant technology to automate manual processes, but also to be aware of emerging technologies. Further, technologically adept accountants will utilize technology to facilitate their ability to communicate within and outside their firms and suggest ways to improve business performance.

Interpretation of Converging Information

Interpretation of converging information requires accountants to consider financial and non-financial factors in order to put information into a broader 
strategic context. Key to this competency is accountants' understanding of the client's business and an ability to integrate and share knowledge with others. Strategic and Critical Thinking Skills

Strategic and critical thinking skills are the final Core Competency. According to the Vision Project, this competency has to do with accountants' ability to "link data, knowledge, and insight to provide quality advice for strategic decision-making" (AICPA 1999, 17). Beyond interpreting converging information, successful accountants of the future will synthesize current and emerging financial and non-financial information in order to predict future opportunities (e.g., growth opportunities). This competency assumes a proactive, forward-looking mindset rather than a traditional, reactive, historical orientation.

\section{AICPA Vision-Aligned Academic Framework}

In 2000, the AICPA posted its Vision-Aligned Academic Framework (AICPA 2000) on the Internet to assist the academic community in developing or modifying curricula to implement the Core Competencies set forth in the previously issued Vision Project. The Framework utilizes three Categories for the Competency Dimensions it describes: (1) functional competencies, (2) personal competencies, and (3) broad business perspective competencies. The AICPA describes each Category as follows: 
- Functional competencies relate to the technical competencies that most closely align with the value accounting professionals contribute to the marketplace (http://www.aicpa.org/edu/func.htm).

- Personal competencies relate to the attitudes and behaviors of individuals preparing to enter the accounting profession. Developing these personal competencies will enhance the way accountants handle professional relationships and facilitate individual learning and personal improvement (http://www.aicpa.org/edu/pers.htm).

- Broad business perspective competencies relate to the context in which accounting professionals perform their services. Individuals preparing to enter the accounting profession should consider both the internal and external business environments and how their interactions determine success or failure. Professionals must be conversant with the overall realities of the business environment (http://www.aicpa.org/edu/bbfin.htm).

Within each of these Categories, the Framework presents Competency Dimensions that suggest more specific activities on which faculty can focus in modifying their courses to implement the Core Competencies. The Competency Dimensions together with their descriptions (per the Framework) are organized by 
Category and appear in Table 2. In the following subsections, which we also organize by Category, we discuss each of the Framework's twenty Competency Dimensions.

\section{INSERT TABLE 2 HERE}

\section{Functional Competencies}

Functional Competencies associate with technical aspects of the job that accountants perform. Competency Dimensions include: (1) Decision Modeling; (2) Risk Analysis; (3) Measurement; (4) Reporting; (5) Research; and (6) Leverage Technology to Develop and Enhance Functional Competencies (AICPA 2000, http://www.aicpa.org/edu/func.htm).

First, Decision Modeling has two important elements: synthesis and analysis. Decision Modeling requires accountants to consider issues and alternatives as well as select and implement solutions in performing their work. Second, Risk Analysis, suggests accountants should understand and integrate business risk analysis into their work. Third, Measurement associates accountants' selection of relevant and reliable measures for various reporting needs. Fourth, the Reporting dimension, indicates accountants need good communication skills, so that they can effectively communicate the results of their work. Fifth, Research describes accountants' ability to obtain the information they need to perform their work. Finally, the Framework recommends accountants Leverage Technology to 
Develop and Enhance Functional Competencies. This Functional Competency Dimension requires accountants to use technology to enable the other dimensions. Personal Competencies

Personal Competencies describe accountants' skills, abilities, behaviors and attitudes. Competency Dimensions include: (1) Professional Demeanor; (2) Problem Solving and Decision Making; (3) Interaction; (4) Leadership; (5) Communication; (6) Project Management; and (7) Leverage Technology to Develop and Enhance Personal Competencies (AICPA 2000, http://www.aicpa.org/edu/pers.htm).

First, Professional Demeanor relates to behavior and conduct (i.e., demonstration of objectivity, integrity, ethical behavior, a strong work ethic, and a commitment to continuous personal improvement). Next, Problem Solving and Decision Making concern accountants' ability to utilize insight, judgment, innovative and creative thinking in solving problems and making decisions. Third, Interaction characterizes accountants' ability to work effectively with others (e.g., to manage their interpersonal relationships). Fourth, Leadership associates with accountants' ability to motivate and direct others in order to achieve results.

Fifth, Communication is the Personal Competency Dimension that relates to accountants' skill in effectively sharing information. Sixth, Project Management incorporates the ability to effectively manage limited resources (e.g., 
time, money, people, technology, etc.). Finally, the Framework recommends accountants "Leverage Technology to Develop and Enhance Personal Competencies" by effectively and efficiently using technology at work.

\section{Broad Business Perspective Competencies}

As business advisors, the AICPA expects accountants to have a broadbased knowledge of the business environment. Accordingly, Broad Business Perspective Competencies have to do with accountants' knowledge of the environment in which they work. Competency Dimensions include: (1) Strategic/Critical Thinking; (2) Industry/Sector Perspective; (3) International/Global Perspective; (4) Resource Management; (5) Legal/Regulatory Perspective; (6) Marketing/Client Focus; and (7) Leverage Technology to Develop and Enhance a Broad Business Perspective (AICPA 2000, http://www.aicpa.org/edu/bbfin.htm).

These dimensions relate to understanding the overall business environment of a client; developing industrial and institutional knowledge beyond technical financial reporting regulations; understanding global political and economic issues; a foundation in business processes and resource management activities; and comprehending the effects of legal and regulatory actions. As with the previously discussed dimensions, accountants are expected to be able to use technology to manage these broad business issues. 


\section{INTEGRATING THE AICPA'S WORKS}

Given the discussion above, there is clearly some overlap between the Core Competencies the Vision Project (AICPA 1999) lists and the Competency Dimensions that the Framework (AICPA 2000) lists. Thus, educators considering curriculum change in implementing the Vision Project's Core Competencies may face some obstacles due to the lack of explicit linkage between the documents. Indeed, part of the difficulty in mapping the Framework's twenty Competency Dimensions into the Vision Project's five Core Competencies stems from the categorization the Framework uses. The Framework suggests there are three categories of Competencies that the academic community needs to develop. In contrast, the Vision Project suggests there are five Core Competencies that successful future accountants need. Thus, to enhance the usefulness of the Vision Project and the Framework, in Table 3, we map the Framework's twenty Competency Dimensions into the Vision Project's five Core Competencies. In doing so, we include the Category that relates to each of the Framework's twenty Competency Dimensions.

In mapping the AICPA's two works, we performed a content analysis (Kerlinger 1986, 479-481) for each Competency Dimension of the Framework (AICPA 2000) to assess the degree to which its theme relates to one or more of the five Core Competencies of the Vision Project (AICPA 1999). Two of the 
researchers and a graduate assistant independently coded the theme of each Competency Dimension as either associating or not associating with the theme of each of the Core Competencies. Inter-coder agreement was over 95\% across all three coders.

\section{TABLE 3 ABOUT HERE}

As shown in Table 3, four of the Framework's Competency Dimensions map to the Vision Project's Core Competency, Communication and Leadership Skills: Reporting; Interaction; Leadership; and Communication. Five of the Framework's Competency Dimensions link to the Vision Project's (AICPA 1999) Core Competency, Focus on Customer, Client and Market: Industry/Sector Focus; International/Global Perspective; Resource Management; Legal/Regulatory Perspective; and Marketing/Client Focus. The Vision Project's Core Competency, Technological Adeptness, associates with three of the Framework's Competency Dimensions: Leverage Technology to Develop and Enhance Functional Competencies; Leverage Technology to Develop and Enhance Personal Competencies; and Leverage Technology to Develop and Enhance a Broad Business Perspective.

Seven of the Framework's Competency Dimensions map to the Vision Project's Core Competency, Interpretation of Converging Information: Decision Modeling; Risk Analysis; Research; Problem Solving and Decision Making; 
Industry/Sector Perspective; International/Global Perspective; and Legal/Regulatory Perspective. Finally, five of the Framework's Competency Dimensions map to the Vision Project's Core Competency, Strategic and Critical Thinking Skills: Decision Modeling; Risk Analysis; Research; Problem Solving and Decision Making; and Strategic/Critical Thinking Skills.

Not surprisingly, across the Vision Project and the Framework, there is a great deal of consistency. In some cases, there is even overlap. That is, some of the Framework's Competency Dimensions (e.g., Decision Modeling) link to more than one of the Vision Project's Core Competencies (e.g., Interpretation of Converging Information and Strategic, and Critical Thinking Skills).

Moreover, we can map all but two of the Framework's Competency Dimensions into the Vision Project's Core Competencies. The two unique Competency Dimensions in the Framework (AICPA 2000) are: Measurement (c.f., technical accounting knowledge); and Project Management. The AICPA's lack of inclusion of Measurement and Project Management in its Vision Project (AICPA 1999) but not in its Framework (AICPA 2000) for educators' curriculum development/reform is likely the result of two factors. The first is the expectation that accounting professionals would possess these minimum skills, whereas the AICPA would expect students to develop these baseline skills during their educational experience. The second is that accounting curricula traditionally has 
done a good job teaching students how to measure business events (Stone 2000, 1). Further, it is possible the AICPA considers the entire college experience a "training ground" for teaching students how to manage time and resources.

\section{CONCLUSIONS}

For accounting educators, pronouncements such as the AICPA's Vision Project (AICPA 1999) and Framework (AICPA 2000) provide a general - but heretofore fragmented - outline for course reengineering and curriculum redesign. Our purpose in this paper is to enhance the usefulness of the AICPA's competency works by illuminating their connections.

As discussed, faculty may encounter difficulty in mapping the Framework's Competency Dimensions into the Vision Project's Core Competencies because the AICPA uses different categorizations in the two documents. The Framework (AICPA 2000) cites three broad competency categories: functional; personal; and broad business perspective. Alternatively, the Vision Project (AICPA 1999) suggests there are five Core Competencies: communications and leadership skills; focus on the customer, client and market; technological adeptness; interpretation of converging information; and strategic and critical thinking skills.

Given the importance of the Framework in developing learning objectives that reflect the Core Competencies articulated in the Vision Project, this paper 
extends the academic literature by mapping each dimension of the Framework to a specific Core Competency. In so doing, this manuscript supports the AICPA's conceptual modeling process by providing an explicit mapping that will help accounting educators in their efforts to expeditiously implement the Core Competencies articulated in the Vision Project.

For example, in formulating learning objectives, faculty may elect to emphasize or de-emphasize particular dimensions in a course. By using the mapping in Table 3, faculty can identify the Competency Dimensions in the Framework (AICPA 2000) that associate with each of the Vision Projects' five Core Competencies (AICPA 1999). This will help enable faculty to point to the market motivation when adopting some or all of the competencies as drivers of content and activities in a particular course. For instance, faculty desiring to hone students' communication and leadership skills can use the linkages set forth in Table 3 to identify four main areas in which they might focus their efforts: reporting, communication, interaction, and leadership.

In this way, Table 3 can serve as a tool to help faculty desiring to innovate their courses. For example, as explained earlier, communication skills relate to individuals' ability to convey information or elaborate on what they know. Thus, to hone students' communication skills, faculty might incorporate into their classes opportunities for the students to report or communicate to their peers 
answers they have formulated (e.g., Choo and Tan 1995; Hermanson 1994; Schadewald and Limberg 1990). Further, leadership abilities relate to one's ability to "influence, inspire and motivate others to achieve results" (AICPA 1999, 17), which is a key facet of teaching (McKeachie 1994). Accordingly, faculty can provide students with opportunities to interact with their peers in a group setting and take turns leading group discussions in order to practice teaching, and thereby improve their leadership abilities.

As the leading professional body for practicing accountants, the AICPA has worked to create a strategic vision that will ensure the future success of the profession. It is important that accounting education adapt to reflect the changing nature of practice and foster the broad set of competencies set forth by the profession's leaders. The linkages set forth in this paper can help educators in directing their curriculum innovation and change to accomplish those goals. In conclusion, although this paper fills a gap in the literature and therefore helps accounting educators move the recommendations of the Vision Project (AICPA 1999) toward implementation, further work remains. For instance, future research needs to test the application of the AICPA's principles through concrete examples of meaningful and substantive curriculum re-design. Evidence on meaningful and lasting curriculum change takes many years to assess. At this time, the AICPA's pronouncements have only been available for less than three 
years, leaving limited opportunities for piloting, implementation and assessment. Additionally, faculty research needs to address the issue of how to assess the success of revised curricula (Apostolou 1999, 193) in enhancing students' grasp of the AICPA-recommended Competencies. Nonetheless, the future of the accounting profession is taking shape under the guidance of the AICPA's initiatives and, through this paper we hope to assist accounting educators in expediting change. 


\section{Acknowledgments}

The authors gratefully acknowledge the valuable comments and suggestions made by the editor, Bill Schwartz, two anonymous reviewers, Lawrence Klein, Andrew Rosman, and David Wiest. We also appreciate input received from participants at the 1999 New England Business \& Economics Association Conference, the 2000 American Accounting Association Northeast Regional Meeting, and the 2001 Connecticut Accounting Forum for Educators. 


\section{References}

AICPA. 1999. Focus on the Horizon, the CPA Profession in 2011. New York: AICPA.

AICPA. 2000. Vision-Aligned Academic Framework. Available at: http://www.aicpa.org/edu/corecomp.htm.

Albrecht, W.S. and R.J. Sack. 2000. Accounting education: Charting the course through a perilous future. Accounting Education Series, Vol. 16, a joint project of: AAA, AICPA, IMA, Arthur Andersen, Deloitte and Touche, Ernst and Young, KPMG, PricewaterhouseCoopers. Sarasota, FL: AAA.

Apostolou, B.A. 1999. Outcomes Assessment. Issues in Accounting Education 14 (1): 177-197.

Bedford Committee. 1986. Future Accounting Education: Preparing for the Expanding Profession. Sarasota, FL: American Accounting Association.

Big 8. 1989. Perspectives on Education: Capabilities for Success in the Accounting Profession. New York: Big 8.

Bonner, S. 1999. Choosing teaching methods based on learning objectives: an integrative framework. Issues in Accounting Education (February): 11-39.

Choo, F. and K. Tan. 1995. Effect of cognitive elaboration on accounting students' acquisition of auditing expertise. Issues in Accounting Education (Spring): 27-45.

Hermanson, D. 1994. The effect of self-generated elaboration on students' recall of tax and accounting material: further evidence. Issues in Accounting Education (Fall): 301-318.

Institute of Management Accountants. 1994. What America Wants in Entry-Level Accountants. Montvale, NJ: The Institute of Management Accountants.

Institute of Management Accountants. 1999. Counting More, Counting Less: Transformations in the Management Accounting Profession. Montvale, NJ: The Institute of Management Accountants. 
Kerlinger, F. N. 1986. Foundations of Behavioral Research, ( $3^{\text {rd }}$ Edition). Fort Worth, TX: Holt, Rinehart and Winston, Inc.

McKeachie, W.J. 1994. Teaching Tips: Strategies, Research and Theory for College and University Teachers ( $9^{\text {th }}$ ed.). Lexington, MA: D. C. Heath and Company.

Schadewald, M. and S. Limberg. 1990. Instructor-provided versus studentgenerated explanations of tax rules: effect on recall. Issues in Accounting Education (Spring): 30-40.

Stone, M. 2000. What will we teach? Accounting Education News (Fall): 1-2, 11.

Walker, K.B. and Penne L. Ainsworth. 2001. Developing a process approach in the business core curriculum. Issues in Accounting Education (November): 41-66. 


\section{Table 1}

Core Competencies per the Vision Project (AICPA 1999, 11)

\begin{tabular}{|c|l|}
\hline $\begin{array}{c}\text { Communications and } \\
\text { Leadership Skills }\end{array}$ & $\begin{array}{l}\text { Able to give and exchange information within a } \\
\text { meaningful context and with appropriate delivery } \\
\text { and interpersonal skills. } \\
\text { Able to influence, inspire and motivate others to } \\
\text { achieve results. }\end{array}$ \\
\hline $\begin{array}{c}\text { Focus on Customer, Client } \\
\text { and Market }\end{array}$ & $\begin{array}{l}\text { Able to anticipate and meet the changing needs of } \\
\text { clients, employers, customers, and markets better } \\
\text { than competitors. }\end{array}$ \\
\hline $\begin{array}{c}\text { Technological Adeptness } \\
\text { Interpretation of Converging } \\
\text { Information }\end{array}$ & $\begin{array}{l}\text { Able to utilize and leverage technology in ways } \\
\text { that add value to clients, customers and } \\
\text { employers. }\end{array}$ \\
\hline $\begin{array}{c}\text { Strategic and Critical } \\
\text { Thinking Skills }\end{array}$ & $\begin{array}{l}\text { Able to interpret and provide a broader context } \\
\text { to provide quality advice for strategic decision- } \\
\text { making. }\end{array}$ \\
\hline
\end{tabular}




\section{Table 2}

\section{Competency Dimensions per Framework (AICPA 2000)} Panel A: Functional Competencies ${ }^{1}$

\begin{tabular}{|l|l|}
\hline \multicolumn{1}{|c|}{ Competency Dimensions } & \multicolumn{1}{c|}{ Descriptions of Competency Dimension } \\
\hline Decision Modeling & Able to consider issues, identify alternatives, and choose/implement solutions \\
\hline Risk Analysis & $\begin{array}{l}\text { Able to identify and manage audit risk and understand how business risk affects } \\
\text { business strategy }\end{array}$ \\
\hline Measurement & $\begin{array}{l}\text { Able to use traditional and non-traditional (e.g., quantitative and qualitative) } \\
\text { measures that are relevant and reliable }\end{array}$ \\
\hline Reporting & $\begin{array}{l}\text { Able to communicate clearly and objectively the work done and the resulting } \\
\text { findings in accordance with professional standards }\end{array}$ \\
\hline Research & Able to access relevant guidance/information, understand it, and apply it \\
\hline $\begin{array}{l}\text { Leverage Technology to } \\
\text { Develop and Enhance } \\
\text { Functional Competencies }\end{array}$ & $\begin{array}{l}\text { Able to use technology tools effectively and efficiently to develop and apply other } \\
\text { functional competencies }\end{array}$ \\
\hline
\end{tabular}

\section{Panel B: Personal Competencies ${ }^{2}$}

\begin{tabular}{|l|l|}
\hline \multicolumn{1}{|c|}{ Competency Dimensions } & \multicolumn{1}{c|}{ Descriptions of Competency Dimension } \\
\hline Professional Demeanor & Demonstrate objectivity and integrity; continuously improve skills and knowledge \\
\hline $\begin{array}{l}\text { Problem Solving and Decision } \\
\text { Making }\end{array}$ & $\begin{array}{l}\text { Use good insight and judgment and innovative and creative thinking to effectively } \\
\text { solve problems and make decisions }\end{array}$ \\
\hline Interaction & Able to work productively with a diversity of individuals \\
\hline Leadership & Able to influence, inspire, and motivate individuals and groups to achieve results \\
\hline Communication & Able to listen, speak and write in order to meaningfully exchange information \\
\hline Project Management & Able to manage assets and technical resources in order to complete projects \\
\hline $\begin{array}{l}\text { Leverage Technology to } \\
\text { Develop and Enhance Personal } \\
\text { Competencies }\end{array}$ & $\begin{array}{l}\text { Stay abreast of changes in technology to enhance the development and application } \\
\text { of other personal competencies }\end{array}$ \\
\hline
\end{tabular}

\section{Panel C: Broad Business Perspective Competencies ${ }^{3}$}

\begin{tabular}{|l|l|}
\hline \multicolumn{1}{|c|}{ Competency Dimensions } & \multicolumn{1}{c|}{ Descriptions of Competency Dimension } \\
\hline Strategic/Critical Thinking & $\begin{array}{l}\text { Able to link data, knowledge, and insight together - from a "big picture" } \\
\text { perspective - to provide information for decision-making }\end{array}$ \\
\hline Industry/Sector Perspective & Able to identify risks/opportunities given a company's industry \& economic sector \\
\hline $\begin{array}{l}\text { International/Global } \\
\text { Perspective }\end{array}$ & $\begin{array}{l}\text { Able to facilitate global commerce by identifying and communicating } \\
\text { threats/opportunities of doing business in a borderless world }\end{array}$ \\
\hline Resource Management & $\begin{array}{l}\text { Able to recognize and allocate resources (human, financial, physical, } \\
\text { environmental, etc.) necessary for participation in the global capital markets }\end{array}$ \\
\hline Legal/Regulatory Perspective & $\begin{array}{l}\text { Able to describe the legal and regulatory environment facing companies } \\
\text { Able to analyze the impact of changes in legal/regulatory requirements }\end{array}$ \\
\hline Marketing/Client Focus & $\begin{array}{l}\text { Able to anticipate and meet the changing needs of clients, employers, customers, } \\
\text { and markets by recognizing market needs and developing new markets }\end{array}$ \\
\hline $\begin{array}{l}\text { Leverage Technology to } \\
\text { Develop and Enhance a Broad } \\
\text { Business Perspective }\end{array}$ & $\begin{array}{l}\text { Able to understand and appreciate the effects of technology on the broader business } \\
\text { environment }\end{array}$ \\
\hline
\end{tabular}

${ }^{I}$ Functional competencies relate to the technical competencies that most closely align with the value accounting professionals contribute (see AICPA [2000, http://www.aicpa.org/edu/func.htm])

${ }^{2}$ Personal competencies relate to the attitudes and behaviors of individuals preparing to enter the accounting profession (see AICPA [2000, http://www.aicpa.org/edu/pers.htm])

${ }^{3}$ Broad Business Perspective Competencies relate to the context in which accounting professionals perform their services (see AICPA [2000, http://www.aicpa.org/edu/fbbfin.htm]) 
Table 3

Mapping of Competency Dimensions per Framework (AICPA 2000) To Core Competencies per Vision Project (AICPA 1999)

\begin{tabular}{|c|c|c|}
\hline $\begin{array}{l}\text { Core Competency } \\
\text { Per Vision Project } \\
\text { (AICPA 1999) }\end{array}$ & $\begin{array}{c}\text { Category of } \\
\text { Competency Dimension } \\
\text { Per Framework } \\
\text { (AICPA 2000) }\end{array}$ & $\begin{array}{c}\text { Competency Dimensions } \\
\text { Per Framework } \\
\text { (AICPA 2000) }\end{array}$ \\
\hline \multirow{3}{*}{$\begin{array}{l}\text { Communication and } \\
\text { Leadership Skills }\end{array}$} & Functional Competencies & $>$ Reporting \\
\hline & Personal Competencies & $\begin{array}{l}>\text { Interaction } \\
>\text { Leadership } \\
>\text { Communication }\end{array}$ \\
\hline & $\begin{array}{l}\text { Broad Business Perspective } \\
\text { Competencies }\end{array}$ & $>(\mathrm{N} / \mathrm{A})$ \\
\hline \multirow{3}{*}{$\begin{array}{l}\text { Focus on Customer, } \\
\text { Client and Market }\end{array}$} & Functional Competencies & $>(\mathrm{N} / \mathrm{A})$ \\
\hline & Personal Competencies & $>(\mathrm{N} / \mathrm{A})$ \\
\hline & $\begin{array}{l}\text { Broad Business Perspective } \\
\text { Competencies }\end{array}$ & $\begin{array}{l}\text { D Industry/Sector Focus } \\
>\text { International/Global Perspective } \\
>\text { Resource Management } \\
>\text { Legal/Regulatory Perspective } \\
>\text { Marketing/Client Focus }\end{array}$ \\
\hline \multirow[t]{3}{*}{$\begin{array}{l}\text { Technological } \\
\text { Adeptness }\end{array}$} & Functional Competencies & $\begin{array}{l}\text { Leverage Technology to Develop and } \\
\text { Enhance Functional Competencies }\end{array}$ \\
\hline & Personal Competencies & $\begin{array}{l}\text { Leverage Technology to Develop and } \\
\text { Enhance Personal Competencies }\end{array}$ \\
\hline & $\begin{array}{l}\text { Broad Business Perspective } \\
\text { Competencies }\end{array}$ & $\begin{array}{l}\text { Leverage Technology to Develop and } \\
\text { Enhance a Broad Business Perspective }\end{array}$ \\
\hline \multirow[t]{3}{*}{$\begin{array}{l}\text { Interpretation of } \\
\text { Converging } \\
\text { Information }\end{array}$} & Functional Competencies & $\begin{array}{l}>\text { Decision Modeling } \\
>\text { Risk Analysis } \\
>\text { Research }\end{array}$ \\
\hline & Personal Competencies & $>$ Problem Solving \& Decision Making \\
\hline & $\begin{array}{l}\text { Broad Business Perspective } \\
\text { Competencies }\end{array}$ & $\begin{array}{l}>\text { Industry/Sector Perspective } \\
>\text { International/Global Perspective } \\
>\text { Legal/Regulatory Perspective }\end{array}$ \\
\hline \multirow[t]{3}{*}{$\begin{array}{l}\text { Strategic and Critical } \\
\text { Thinking Skills }\end{array}$} & Functional Competencies & $\begin{array}{l}>\text { Decision Modeling } \\
>\text { Risk Analysis } \\
>\text { Research }\end{array}$ \\
\hline & Personal Competencies & $>$ Problem Solving \& Decision Making \\
\hline & $\begin{array}{l}\text { Broad Business Perspective } \\
\text { Competencies }\end{array}$ & $>$ Strategic/Critical Thinking Skills \\
\hline \multirow[t]{3}{*}{ (N/A) } & Functional Competencies & $>$ Measurement \\
\hline & Personal Competencies & $>$ Project Management \\
\hline & $\begin{array}{l}\text { Broad Business Perspective } \\
\text { Competencies }\end{array}$ & $>(\mathrm{N} / \mathrm{A})$ \\
\hline
\end{tabular}

